\title{
THE USE OF STATISTICAL PROCESS CONTROL TOOLS FOR ANALYSING FINANCIAL STATEMENTS
}

Janusz Niezgoda, Ph.D.

Cracow University of Economics

Faculty of Management

Department of Statistics

Rakowicka 27, 31-510 Kraków, Poland

e-mail:januszni@uek.krakow.pl

Received 4 January 2017, Accepted 4 January 2017

\begin{abstract}
This article presents the proposed application of one type of the modified Shewhart control charts in the monitoring of changes in the aggregated level of financial ratios. The control chart $\bar{x}$ has been used as a basis of analysis. The examined variable from the sample in the mentioned chart is the arithmetic mean. The author proposes to substitute it with a synthetic measure that is determined and based on the selected ratios. As the ratios mentioned above, are expressed in different units and characters, the author applies standardisation. The results of selected comparative analyses have been presented for both bankrupts and non-bankrupts. They indicate the possibility of using control charts as an auxiliary tool in financial analyses.
\end{abstract}

Keywords: control charts, synthetic variable, financial analysis

JEL classification: C00, G33 


\section{Introduction}

Shewhart control charts belong to the most important tools of statistical quality control. They were developed in the 1920s and are mainly used to provide convenient tools to support decision-making concerning manufacturing processes in the case of the systematic inflow of figures. Over time, control charts have also been used for non-manufacturing purposes. The proposal by Pawłowski (1969) is worth attention as he suggests using the modification of a typical control chart for forecasting. This study is an attempt to present a proposal to track changes in financial statements in order to forecast potential signals indicating the potentially deteriorated financial standing of enterprises. The analysis presents a control chart in which a synthetic measure has been used as a variable from the sample.

\section{The functioning of Shewhart control charts}

The control charts created by Walter A. Shewhart were introduced in the 1920s. Shewhart noted that the variables which described manufacturing processes had a normal distribution and natural variability in the range of mean plus/minus three standard deviations. The process with the mean falling into this range is considered to be stable (under control). If the mean of the process takes values which do not belong to the natural variability range, the out-of-control signal appears in consequence of special causes. Based on that, Shewhart developed monitoring procedures whose main elements are called control charts.

In the case of monitoring the process characterised by a variable which is a nominant, centre line (CL) and lines which determine the range of the typical variability of the analysed statistics: upper control limit (UCL) and lower control limit (LCL) are placed on a typical control chart. Points representing an out-of-control process are found above the upper or below the lower control limit as shown in Figure 1 which are process control limits. In the case when the monitored variable is a stimulant, the lower control limit is the limit of regulation (control). Points below the lower control limit indicate that the process is out of control. The upper control limit is drawn for variables which are destimulants. Points above the upper control limit indicate that the process is out of control. The described signals are points which are out-of-control signals. Other signals noted are a series of out-of-control signals. 


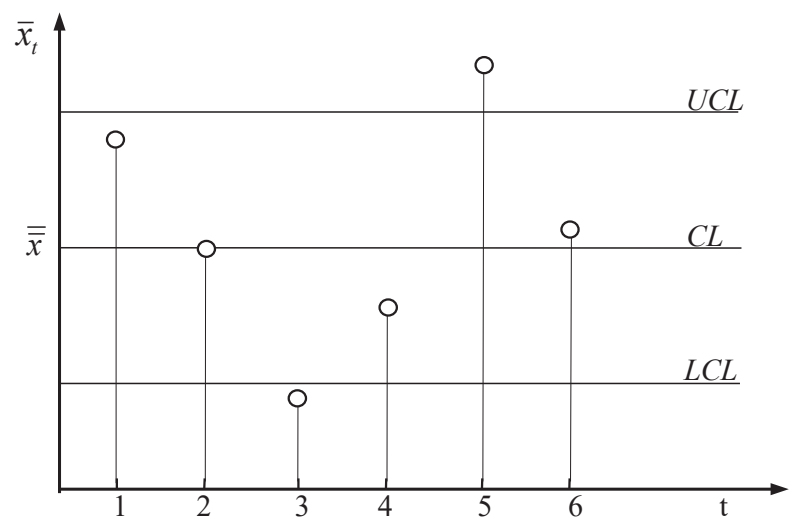

Figure 1. Shewhart control chart

Source: own study.

Control charts $\bar{x}, \bar{x}-s, \bar{x}-r$ are most frequently used to monitor processes which are described by variables of normal probability distribution. Control chart parameters $(C L, U C L$ and $L C L$ levels) are determined with the use of a design (normative) or stabilisation method. In the design method, the $C L$ level is determined by the value resulting from the documentation of the manufactured product. The detailed procedure can be found in (Iwasiewicz, 2005). If normative values are not available, the position of $C L$ is determined and based on the preliminary observation of the process and it is marked on the level of mean $\overline{\bar{x}}$ for the period. Details can be found in (Iwasiewicz, 2005; Hamrol, 2007). The variable from the sample for the control chart $\bar{x}$ is the mean of the values obtained from the sample for the period $t\left(\bar{x}_{t}\right)$. Control line parameters may be determined and based on the following formulas:

where:

$$
\begin{aligned}
& U C L=\overline{\bar{x}}+u_{\alpha / 2} \frac{s}{\sqrt{n}} \\
& L C L=\overline{\bar{x}}-u_{\alpha / 2} \frac{s}{\sqrt{n}}
\end{aligned}
$$

$n$ - size of the sample,

s - standard deviation estimator obtained based on the preliminary analysis of the process,

$u_{\alpha / 2}-$ normal distribution quantile. 
In practice, it is often assumed that $u_{\alpha / 2}=3$; then:

$$
\begin{aligned}
& U C L=\overline{\bar{x}}+3 \frac{s}{\sqrt{n}} \\
& L C L=\overline{\bar{x}}-3 \frac{s}{\sqrt{n}}
\end{aligned}
$$

In the situation when it is impossible to collect a sample larger than one or it is not justified due to costs, a modified control chart $\bar{x}$ can be used. The modification involves unit sampling and the used chart is referred to as chart $x$.

\section{Adopted research procedure}

The research procedure was based on the Shewhart control chart $x$. It was used to analyse the synthetic variable $q_{i}$ in the following form:

$$
q_{i}=\sum_{j=1}^{k} w_{j} q_{i j}
$$

where:

$q_{i j}$ - standardised $i$-th value of $j$-th ratio,

$w_{j}$ - weight coefficient assigned to $j$-th ratio.

Weight coefficients are supposed to describe the "significance" of individual variables. But they must fulfil two conditions (Iwasiewicz, 2005). The first one is about assigning values in the following way: the more "significant" a given variable, the greater the value of the ratio. The other condition is as follows:

$$
\sum_{j=1}^{k} w_{j}=1
$$

Considering the various nominals and diverse characters of the analysed indicators, variables were standardised, using the normalisation method. The literature most often refers to the issue of symmetrical nominants with one target value whereas in the case of financial ratios the situation is slightly more complicated. The ranges of the desired values in the form of $\left[x_{d . j}, x_{g . j}\right]$ are most frequently determined or a single target value is given as an approximate value. It should be stressed that the increase in the value of the ratio above the upper range limit $x_{g . j}$ is not evaluated in the same way as the decrease below the lower range limit $x_{d . j}$. If values 
higher than $x_{g . j}$ are more favourable, then it is a right-tailed asymmetric nominant. The issue of range nominants and their standardisation is described in detail in (Kowalewski, 2006).

Ratios which are nominants have been standardised with formula (7). Right-tailed asymmetric nominants with a recommended range of values (Kowalewski, 2006):

$$
q_{i j}=\left\{\begin{array}{cl}
1 & ; x_{i j} \in\left[x_{d . j} ; x_{g . j}\right] \\
\frac{-1}{k_{p}\left(x_{i}-x_{d . j}-1\right)} & ; x_{i j}<x_{d . j} \\
\frac{1}{k_{l}\left(x_{i}-x_{g . j}+1\right)} & ; x_{i j}>x_{g . j}
\end{array}\right.
$$

where:

$x_{i j} \quad-i$-th standardised value of $j$-th variable,

$x_{d . j} \quad$ - lower range limit of desired values,

$x_{g . j} \quad$ - upper range limit of desired values,

$k_{l}, k_{p}$ - asymmetry constants. In the case of a symmetrical nominant $k_{l}=k_{p}=1$. If the right-tailed asymmetric nominant is described, then $k_{p}$ is the asymmetry constant whereas $k_{l}=1$. For the left-tailed asymmetric nominant $k_{p}=1, k_{l}$ functions as the asymmetry constant. The greater the asymmetry, the higher should be the value of $k_{l}$ or $k_{p}$.

The standardisation of stimulants was based on the following formula:

$$
q_{i j}=\frac{x_{i j}-x_{j . d}}{x_{j . g}-x_{j . d}}
$$

whereas for destimulants:

$$
q_{i j}=\frac{x_{j . g}-x_{i j}}{x_{j . g}-x_{j . d}}
$$

In order to determine the parameters of the modified control chart used to analyse the empirical data, the data was standardised with the use of formulas (7), (8) and (9). Then, arithmetic means were calculated for individual variables. These means $\bar{x}_{j}$ are used to determine centre lines for $C L_{j}$ and standard deviations $s_{j}$. The control limit level for $j$-th variable $\left(U C L_{j}\right.$ and $L C L_{j}$ ) was calculated and based on equations (3) and (4). Control chart parameters are described by formulas (10), (11) and (12): 


$$
\begin{gathered}
C L=\sum_{j=1}^{k} C L_{j} w_{j} \\
U C L=\sum_{j=1}^{k} U C L_{j} w_{j} \\
L C L=\sum_{j=1}^{k} L C L_{j} w_{j}
\end{gathered}
$$

Since the analysed synthetic variable $q_{i}$ is a stimulant, $L C L$ is a limit which, if exceeded in minus, will cause an out-of-control signal.

\section{Empirical data analysis}

The financial ratios of the selected trade companies mentioned in Table 1 have been analysed. The ratios were chosen and based on Dębkowska (2012) and Wędzki (2009). Table 1 also specifies the nature of the ratio by determining whether a given variable should take values belonging to the range limited on both ends (nominant) or whether the range of desired values has a lower limit (stimulant), or whether it has an upper limit and the examined ratio is a destimulant. It should be emphasised that all nominants are right-tailed asymmetric ones.

Table 1. Financial ratios

\begin{tabular}{|l|c|}
\hline \multicolumn{1}{|c|}{ Ratio } & Nature of ratio \\
\hline Current ratio & nominant \\
\hline Quick ratio & nominant \\
\hline Acid test ratio & nominant \\
\hline Debt to equity ratio & destimulant \\
\hline Return on equity & stimulant \\
\hline Receivable turnover & nominant \\
\hline Fixed asset turnover & stimulant \\
\hline Asset turnover & stimulant \\
\hline
\end{tabular}

Source: author's study based on Sierpińska, Jachna (2004) and Tarczyński (1994).

The values between the 10th and the 80th percentile were taken as the nominal values of ratios. The lower range limit of permissible values for stimulants is determined at the level of the 10th percentile whereas the upper range limit of permissible values for destimulants is the 80th percentile. The analysis was based on data from EMIS Intelligence - Poland database. The control chart parameters were determined for 2004 data. Identical weight values $w_{j}=0.125$ were taken for calculations and it was assumed that all indicators were equally significant. 


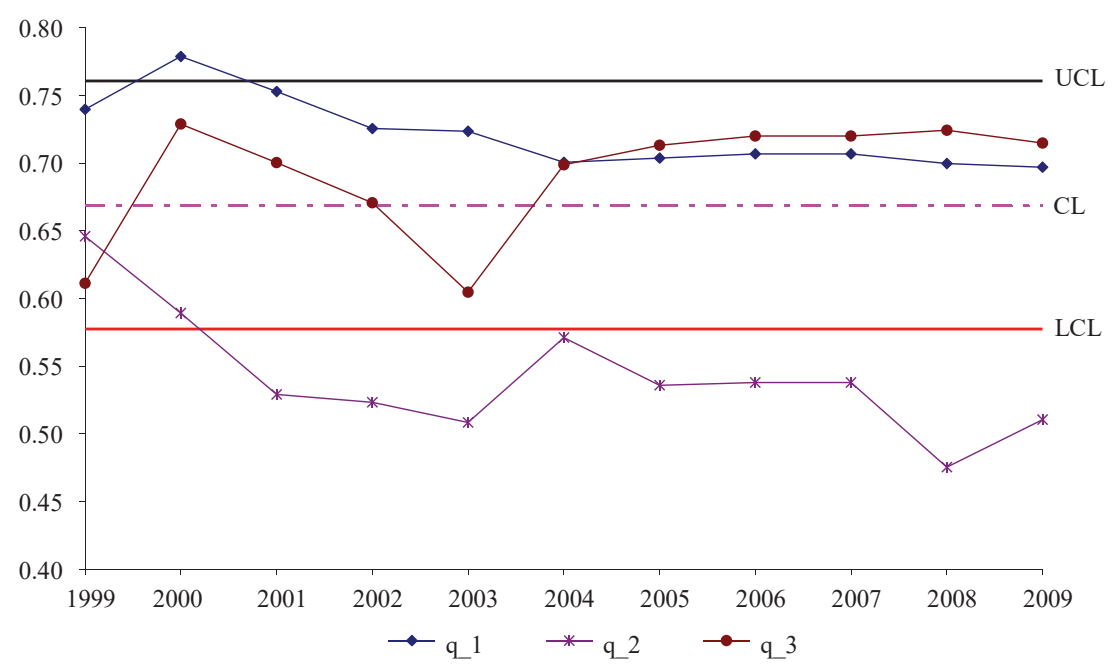

Figure 2. Impact of the symmetry factor on the graph of variable $q$ for $k_{p}=1.1$

Source: own study.

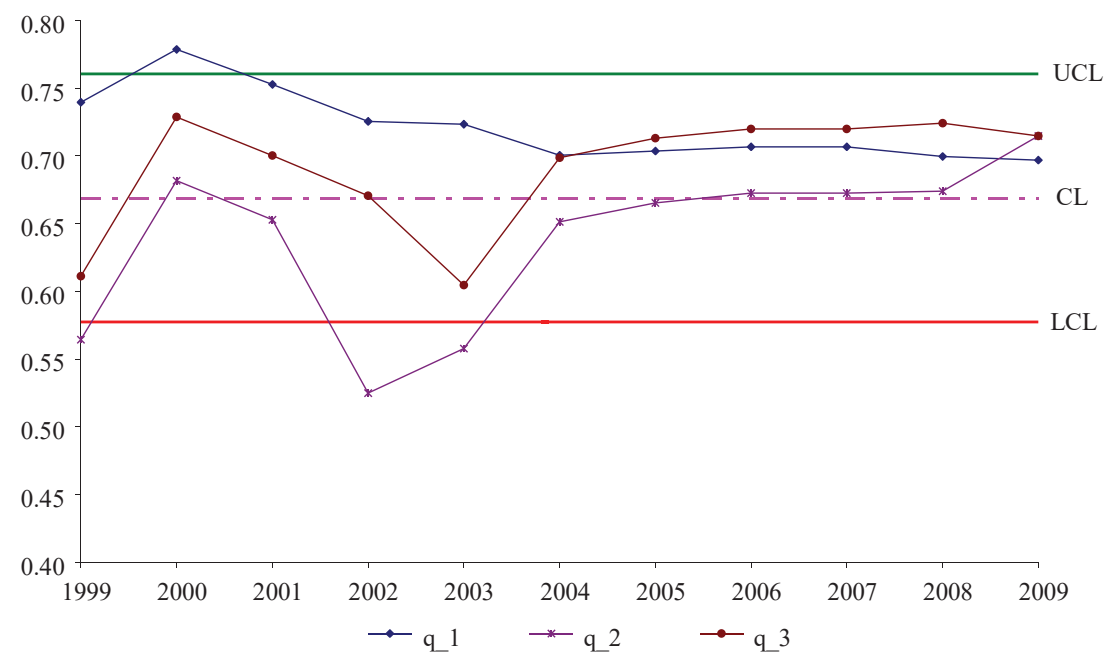

Figure 3. Impact of the symmetry factor on the graph of variable $q$ for $k_{p}=2.0$

Source: own study. 


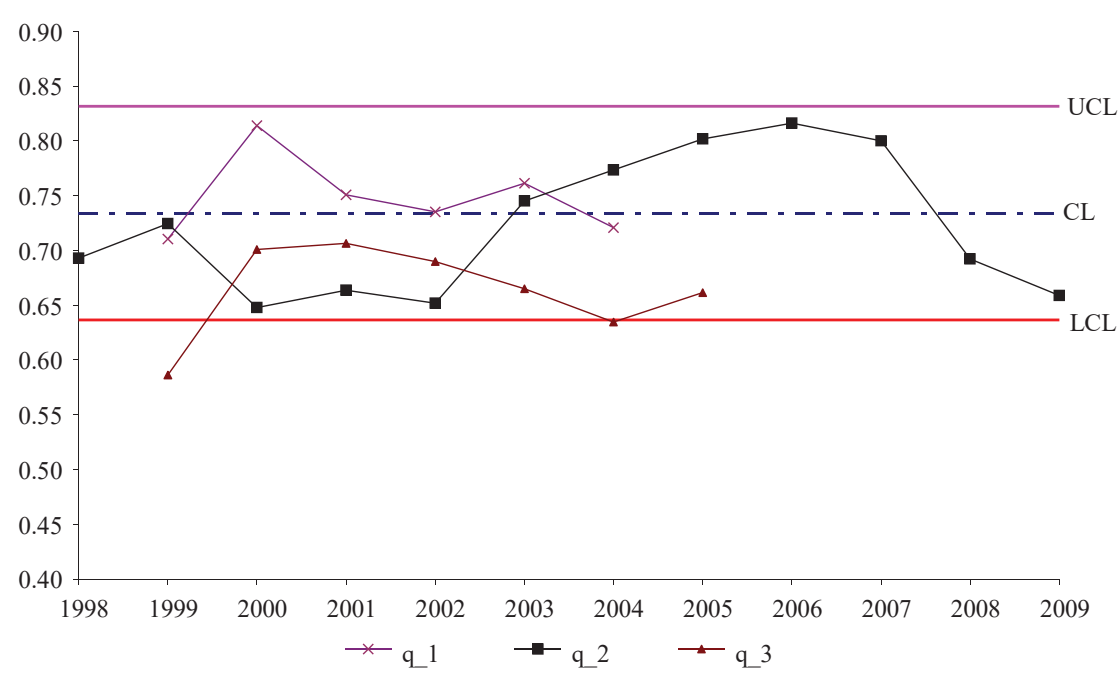

Figure 4. Impact of the symmetry factor on the graph of variable $q$ for $k_{p}=1.1$

Source: own study.

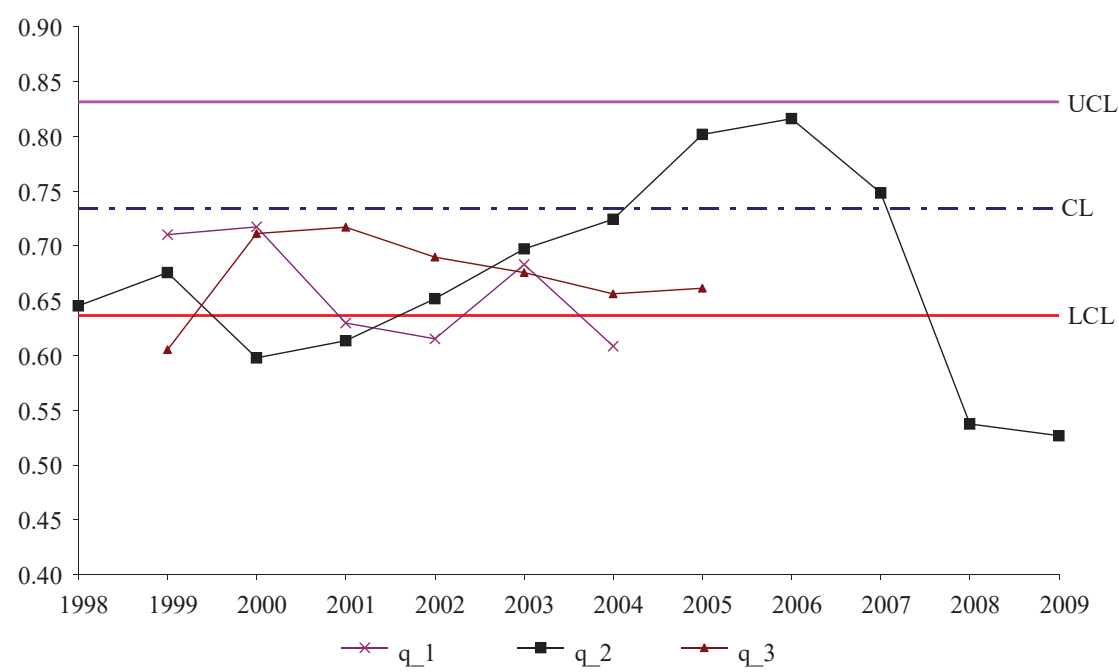

Figure 5. Impact of the symmetry factor on the graph of variable $q$ for $k_{p}=2.0$

Source: own study. 


\section{Conclusions}

Figures 2-4 demonstrate the results of the calculations made. The control charts shown in Figures 2 and 3 have been developed for the same trade companies which did not go bankrupt. The application of two values of the $k_{p}$ ratio resulted in the recording of various behaviours. The higher value $k_{p}$ seems to reflect better the asymmetry of the used ratios which are nominants. Figures 4 and 5 present control charts for the same companies which went bankrupt. The impact of $k_{p}$ on the graphs is noticeable, as before. For a greater value of $k_{p}$ in Figure 5, one can observe that the lower control limit is exceeded and this entails points that are out-of-control signals. This is indicative of the worsening general situation of the analysed enterprise. In the case of the bankrupt companies, graphs are below the centre line more often than those for the nonbankrupt ones.

The control charts may indicate the deteriorating standing of an enterprise in advance. For this reason, the use of the charts for the analysis of financial statements seems to be useful.

\section{References}

Dębkowska, K. (2012). Prognozowanie upadłości przedsiębiorstw za pomocą wybranych metod wielowymiarowej analizy statystycznej. Zarzadzanie i Finanse, 10 (1), 175-184.

Hamrol, A. (2007). Zarządzanie jakościa z przykładami. Warszawa: Wydawnictwo Naukowe PWN.

Iwasiewicz, A. (2005). Zarządzanie jakościa w przykładach $i$ zadaniach. Tychy: Śląskie Wydawnictwo Naukowe Wyższa Szkoła Zarządzania i Nauk Społecznych w Tychach.

Kowalewski, G. (2006). Jeszcze o nominantach w metodach porządkowania liniowego zbioru obiektów. Taksonomia 13, Prace Naukowe Akademii Ekonomicznej we Wrocławiu, 1126, 519-528.

Pawłowski, Z. (1969). Predykcja za pomocą kart kontrolnych. Przegląd Statystyczny, 3-4.

Sierpińska, M., Jachna, T. (2004). Ocena przedsiębiorstwa wedtug standardów światowych. Warszawa: Wydawnictwo Naukowe PWN.

Tarczyński, W. (1994). Taksonomiczna miara atrakcyjności inwestycji w papiery wartościowe. Przegląd Statystyczny, 3, 275-299.

Wędzki, D. (2009). Analiza wskaźnikowa sprawozdania finansowego, Volume 2. Kraków: Wolters Kluwer Polska. 